\title{
Private Savings in the Arab Countries: Empirical Analysis and Policy Implications
}

\author{
Samih Antoine Azar ${ }^{1}$, Ali Bolbol${ }^{2}, \&$ Alexandre Mouradian ${ }^{3}$ \\ ${ }^{1}$ Faculty of Business Administration \& Economics, Mexique Street, Kantari, Beirut, Lebanon \\ ${ }^{2}$ Chief Economist, BLOM Bank, Beirut, Lebanon \\ ${ }^{3}$ Head of Investors Relations, BLOMINVEST Bank, Beirut, Lebanon \\ Correspondence: Samih Antoine Azar, Full Professor, Faculty of Business Administration \& Economics, \\ Mexique Street, Kantari, Beirut, Lebanon. E-mail: samih.azar@haigazian.edu.lb
}

Received: April 25, 2018

doi:10.5539/ijef.v10n7p10
Accepted: May 8, 2018

Online Published: May 30, 2018

\begin{abstract}
In the past two decades, Arab countries have had their fair share of political instability and economic dislocations. They have also experienced relatively low national savings - at close to $24 \%$, more than $10 \%$ less than the Asian economies. This paper looks at how private savings can be invigorated so as to finance more investment and growth, especially in the presence of persistent budget deficits. It develops a simple macroeconomic equation for the determinants of private savings, and uses a novel econometric approach - Robust Least Squares - to estimate that equation for a sample of ten Arab countries across the three sub-regions of the Gulf, West Asia, and North Africa, for the annual 1994-2015 period. The paper finds that Arab private savings compensate for government dis-savings and help ameliorate pressures on the current account and exchange rates. It also finds that Arab private savings are closely related to long-run Arab GDP growth ala the life cycle hypothesis, and proposes policies to enhance the mutual growth of Arab private savings and GDP.
\end{abstract}

Keywords: Arab private saving, current account, foreign exchange rate, panel least squares, robust least squares

\section{Introduction}

Savings is one of the most fundamental variables in economics. It is essential for not limiting aggregate demand in the short term, and crucial for funding enough investments and growth in the long term. Its importance is not only restricted to short-and long-term internal stability, though, and surpasses it to affect greatly external stability. This is simply because savings is organically tied to the current account, and consequently has vital effects on the course of foreign reserves and exchange rates.

These notions are of tremendous economic significance to all countries, and perhaps more so to the Arab countries. In the past twenty years, the Arab world has struggled with low and volatile growth, high unemployment, and external imbalances, not to mention the significant political instability that has plagued its economies (Note 1). Arab national savings also lagged behind emerging economies, registering as a ratio of GDP 24.4\%, against 31.5\% for middle income countries and 36.2\% for the dynamic Asian economies. Given this performance, it is interesting then to see what role did private savings - as opposed to the politically-driven government savings - have in engendering these outcomes; and, more important, what role could it play to enhance the potential and growth of the Arab economy.

That is what we like to investigate in this paper. We will do that by employing three novel innovations. The first is that we will work with a sample of ten Arab countries only, covering the three Arab sub-regions across the Gulf, West Asia, and North Africa, for the period stretching from 1994 to 2015 (Note 2). Second, we will derive a simple but representative one-equation model for the determinants of private savings from standard macroeconomic relationships, making our model theoretically-based and not ad hoc. Third, we will use a new econometric technique, Robust Least Squares, which is seldom employed in the literature but that we think fits rather well the diverse Arab countries in our sample.

We will proceed with the paper as follows. Section 2 will present the basic model for the fundamental determinants of Arab private savings. Section 3 represents the bulk of our paper, and will analyze the econometric results as to what affects private savings in the Arab countries. Section 4 will provide an evaluation 
of the main results, and derive policy implications targeted to improve Arab private savings behavior. Section 5 will conclude the paper, the main idea of which is that private savings has acted as a stabilizing factor in the struggling Arab economy, but can have a more potent impact if long term policies are designed to increase it and to increase sustainable economic growth along with it.

\section{Model and Basic Determinants}

\subsection{National Accounts and Private Savings}

The relation between savings and the current account, in addition to investment can be derived from simple models of national income accounting (Note 3). These imply the following identity:

(1) $\mathrm{S}-\mathrm{I}=\mathrm{CA}$

Equation (1) is the fundamental macroeconomic relation that shows that the excess of national savings over national investment is equivalent to the current account, and vice versa (Note 4). Perhaps more revealing, (1) can be rewritten as:

(2) $\mathrm{S}=\mathrm{I}+\mathrm{CA}$

where (2) indicates that national savings can be used to fund national investments in addition to investments in foreign assets that are equal in magnitude to the current account surplus, and vice versa (Note 5).

Of course, savings in the national economy is divided between the public and private sectors (Note 6). To assess the behavior of each within the context of the macro-economy, (2) can be reformulated as:

(3) $S_{p}-I_{p}+S_{g}-I_{g}=C A$

where $S_{p}$ and $I_{p}$ are private savings and investment respectively; and, similarly, $S_{g}$ and $I_{g}$ are public savings and investment. Since $S_{g}=T-I N-C_{g}$, where T is government revenues, IN is interest payments on the debt, and $C_{g}$ is public consumption (Note 7); and since $\mathrm{T}-\mathrm{IN}-\mathrm{Cg}-\mathrm{I}_{\mathrm{g}}$, where $\mathrm{I}_{\mathrm{g}}$ is public investment or capital expenditures, is equal to the budget balance; then we get $S_{g}-I_{g}$ as equal to the budget balance. Hence, (3) becomes:

(4) $\mathrm{S}_{\mathrm{p}}-\mathrm{I}_{\mathrm{p}}+$ budget balance $=\mathrm{CA}$

Equation (4) shows the interesting relation that, even in the case where private savings is in excess of private investment, the current account could be negative if the budget deficit is too large (its absolute value is larger than $S_{p-} I_{p}$ ), to generate what is famously known as the "twin deficits". In the case where private savings is less than private investment, then each of $\mathrm{S}_{\mathrm{p}}-\mathrm{I}_{\mathrm{p}}$, budget balance, and CA is negative, and we have what we can aptly call "triple deficits" (Note 8). Hence, relieving pressure on the current account requires strengthening private savings, for a given level of investment. And to do that, and to understand the "global" behavior of private savings, we need to know its determinants.

\subsection{Determinants of Private Savings}

One way of modeling private savings is to work through the determinants of equation (4). Starting with private investment, the simple formulation of investment is to assume it a function of the real interest rate, $\mathrm{R}$, and the growth rate of real GDP (expressed as simply GDP), ala the accelerator theory:

(5) $I_{p}=f(R, G D P)$

As to the current account, we can simply make it dependent on income, $\mathrm{Y}$, and the in the real effective exchange rate, $\mathrm{FX}\left(\mathrm{FX}=\mathrm{EP} / \mathrm{P}^{*}\right.$, where $\mathrm{P}$ is the domestic price level, $\mathrm{E}$ is the nominal exchange rate or the price of 1 unit of domestic currency in terms of foreign currency, and $\mathrm{P}^{*}$ is the weighted foreign price level):

(6) $\mathrm{CA}=\mathrm{f}(\mathrm{Y}, \mathrm{FX})$

Assuming the budget balance is exogenous (predetermined by the political process), we can utilize (5) and (6) to formulate from (4) the basic determinants of private savings as:

(7) $\mathrm{S}_{\mathrm{p}}=\mathrm{f}(\mathrm{R}, \mathrm{GDP}, \mathrm{Y}, \mathrm{FX}$, budget balance)

Equation (7) is pretty much the standard functional form for private savings in the literature (Note 9). It depends on non-policy determinants as given by the growth rate of real income, GDP, and by the standard of living, Y; and on policy determinants as reflected by the real interest rate, $R$, for monetary policy, by the budget balance for fiscal policy, and by the real effective exchange rate, FX, for exchange rate policy.

\subsection{Evidence on the Determinants}

The international evidence on the determinants of private savings as given in equation (7) is quite mixed. Evidence on R could go both ways, depending on whether the substitution effect outweighs the income effect or 
not (Note 10). Regarding the growth rate of GDP, the evidence is unequivocal and it is positive. This lends support to the life-cycle hypothesis since growth tends to increase the income of the young (savers) relative to that of the old (dis-savers). The evidence on Y, or per-capita income, is positive for the catching-up lower-or middle-income countries, but neutral for high-income countries. As to FX, the evidence is again mixed. The reason is that, for instance, depreciation in the real exchange rate lowers real wages and hence household savings; whereas, by lowering real wages, it increases corporate profits and hence corporate savings; and, as a result, the balance of the effect is ambiguous (Note 11). Another reason is that, on the one hand, depreciation increases uncertainty and hence increases private savings (besides potentially increasing exports and GDP) (Note 12); whereas, on the other hand, it reduces the dollar value of domestic assets and reduces private savings as a result. Lastly, the evidence on budget balance is mostly positive, in the sense that worsening budget balances worsens private savings (Note 13).

Naturally, equation (7) does not capture all the determinants of private savings (Note 14). Of the crucial social ones, we can list: the dependency ratio, whose evidence is negative in accordance with the life-cycle hypothesis (Note 15); religion, whose evidence is also negative since more religiosity means "it is all in God's hands"; and trust, whose evidence is positive because of its better impact on institutional quality and economic performance (Note 16). Of the missing economic variables from equation (7), two important ones stand out: capital account liberalization and available liquidity (credit extension), with a negative impact for each, because the former allows foreign savings to substitute for private savings, whereas the latter reduces the need for it (Note 17).

\section{Estimation and Empirical Results}

\subsection{Data Sources}

All data were taken and calculated from the World Bank Database (worldbank.com), except for the real effective exchange rate which was taken from the Bruegel Database (Bruegel.org) and the deposit rates for UAE and Qatar which were obtained from private banking sources. As indicated earlier, the data covers annually the period from 1994 to 2015.

\subsection{Sample Countries}

There are ten countries in the sample: four countries classified as GCC (Gulf Cooperation Council) which are Kuwait, Qatar, Saudi Arabia, and United Arab Emirates; three countries classified as Maghreb which are Algeria, Morocco, and Tunisia; and three countries classified as Mashrek, which are Egypt, Jordan, and Lebanon. With the exception of Tunisia and Egypt for the 2011-2013 period, these countries were only indirectly affected by the "Arab Spring", and we think that they represent a normal, representative sample as good as could possibly be available.

In addition, six countries - Kuwait, Qatar, Saudi Arabia, United Arab Emirates, Jordan, and Lebanon - follow a hard peg to the USD and have a liberal economic and financial order (Note 18). Egypt follows a dirty float exchange rate system with a largely liberal economic and financial regime. Both Algeria and Morocco follow a soft peg to a basket of USD and EUR, but Morocco's economic and financial system is mostly liberal whereas that of Algeria is somewhat so (Note 19). Tunisia's exchange rate system targets usually a low a level of the real effective exchange rate and its economic and financial system is fairly liberal.

As important, for countries with a hard peg to the USD, interest rates are determined by US rates plus a risk premium (Note 20). But though nominal interest rates escape full control, real rates don't, and Central Banks can induce changes in them by seeking changes in inflation rates. And the same holds true with respect to exchange rates. Though the nominal exchange rate is fixed, the real exchange rate is not, and can change with changes in the countries' inflation rates relative to that of their trading partners, thus causing depreciations and appreciations in the real exchange rate.

\subsection{Descriptive Statistics}

There are six different variables. These are: SAV (private saving over GDP or private saving rate), GDP (the growth rate in real GDP), YCAP (per-capita GDP), FX (the real effective foreign exchange rate), BOY (the budget balance over GDP), and INT-INF (real interest rate expressed here as the difference between INT, the average nominal deposit rate, and the inflation rate INF). As can be seen from table (1), what is striking is the fact that all-encompassing and stacked variables do not follow normal distributions (Note 21). This, however, is not surprising in view of the high heterogeneity of each variable. Since the standard deviation has the same units as the mean or the median, we can compare these across all aggregated series (all statistics are in percentages except for the GDP per capita and the effective foreign exchange rate). The highest overall mean is for the saving rate which scores $28.58 \%$, and the minimum is the aggregated budget balance over GDP which stands at $1.04 \%$. 
The highest overall standard deviation is $11.99 \%$ and is for the budget balance over GDP, and the smallest overall standard deviation is for the growth rate of GDP at $4.41 \%$. Finally, the overall mean for GDP per capita is very high at $\$ 14,725$, but the median is much lower at $\$ 5,285$, which is a sign of positive skewness or inequality in income distribution. This feature of the data is driven by the high GDP per capita of the GCC countries (Note 22).

Table 1. Descriptive statistics

\begin{tabular}{cccccccccc}
\hline & \multicolumn{3}{c}{ Growth In } & GDP Per & \multicolumn{2}{c}{ Effective } & \multicolumn{2}{c}{ Budget Deficit } & \multicolumn{2}{c}{ Nominal } & \multicolumn{2}{c}{ Inflation } & \multicolumn{2}{c}{ Real Interest Current Account } \\
& Saving Rate & GDP & Capita & Exchange Rate & Over GDP & Interest Rate & Rate & Rate & Balance Over GDP \\
\hline Mean & 28.58469 & 4.789659 & 14725.38 & 106.8362 & 1.044205 & 5.207100 & 4.024423 & 1.182677 & 3.593223 \\
Median & 27.04200 & 4.019000 & 5285.625 & 103.8139 & -2.425500 & 4.815000 & 3.077000 & 1.384000 & 0.159000 \\
Maximum & 54.96400 & 30.01200 & 101723.7 & 163.2800 & 43.30300 & 16.38000 & 29.80000 & 15.19600 & 45.46000 \\
Minimum & 4.529000 & -7.076000 & 978.5370 & 69.63520 & -28.72400 & 0.100000 & -4.860000 & -17.00000 & -31.98700 \\
Std. Dev. & 9.999624 & 4.406099 & 19473.10 & 15.55964 & 11.99282 & 3.148467 & 4.298938 & 4.355770 & 15.13223 \\
Probability & 0.002629 & 0.000000 & 0.000000 & 0.000000 & 0.000000 & 0.000000 & 0.000000 & 0.000000 & 0.018893 \\
\hline
\end{tabular}

\subsection{Empirical Estimation}

Based on equation (7), the estimated model's dependent variable is SAV, which is the private saving rate. The five independent variables are: (1) real growth in GDP (GDP); (2) GDP per capita (YCAP); (3) real effective foreign exchange rate (FX); (4) budget balance over GDP (BOY); and (5) real interest rate (INT-INF).

We have chosen two different econometric procedures to analyze the data: the Autoregressive Distributed Lag (known as ARDL), and Robust Least Squares (which we will call RLS). The ARDL method is useful when the variables are non-stationary, and it has two advantages: it does not impose the same lag structure to all variables like VAR methods, and is applicable in the presence of both non-stationary and stationary variables. The robust least squares method is especially designed and recommended when there are outliers in the data. In this respect the descriptive statistics has already shown the extreme heterogeneity of the data. We have chosen to correct for outliers in both the dependent variable and in the independent variables. This is known as MM estimation. Unfortunately the RLS method does not allow for AR and MA terms, so the estimates are mainly long run estimates. However, the covariances are adjusted for autocorrelation and heteroscedasticity of the regression residuals. This is in contrast to ARDL which corrects only for autocorrelation but not for heteroscedasticity. An additional quality for RLS is that it is seldom used in the empirical literature. So, its use in this paper is quite original and extraordinary, and should give more credence to the results, while being more appropriate and more novel.

The regressions within the ARDL framework are tabulated in the upper part of tables (2) to (5). The regressions RLS are tabulated in the lower part of each table. Table (2) presents the regressions for the whole sample size. There are 210 observations for ARDL and 220 for RLS. Table (3) is for the GCC results separately, and the sample size is 84 for ARDL and 88 for RLS. Table (4) is for the sample of Maghreb countries; table (5) is for the sample of Mashrek countries; and tables (4) and (5) include each 60 observations for ARDL and 66 observations for RLS. The reason for the loss of degrees of freedom for the ARDL procedures is the fact that all ARDL specifications select one lag for the dependent and independent variables, whereas the RLS procedures do not specify lags.

\subsubsection{Coefficient on GDP}

Since we have four samples we will have four estimates of the impact of the real growth in GDP upon the saving rate. We start with the 4 estimates with the ARDL method. The estimated impacts are: 1.1978 (in Table 2), 0.0844 (in Table 3), -0.0839 (in Table 4), and 2.6319 (in Table 5). The expected impact sign is positive. The estimated impact is negative for Maghreb countries but is statistically insignificant with an absolute t-statistic of 0.1534. The remaining 3 impacts are positive. One of them is not statistically significant for GCC countries with a t-statistic of 0.3814. The last two impacts, for the whole sample and for Mashrek countries have respectively t-statistics of 3.0712 with a two-tailed p-value of 0.0027 , and 15.1056 with a two-tailed p-value of 0.0000 . Incidentally, the Mashrek countries have the highest impact and significance (2.6319) which is interpreted as follows. A one percent increase in the real growth increases the saving rate by $2.6319 \%$. Since the impacts are insignificant for GCC countries and for Maghreb countries, the fact that the whole sample provides for a significant impact is probably due to the effect of Mashrek countries. Hence the coefficient on the whole sample 
must be in between zero and 2.6319, and if this coefficient is in the middle of the range it should be half of 2.6318, which is 1.3159 . The actual figure is very close at 1.1978. In what concerns the short run regressions appended to the ARDL table, the only statistically significant impact is the one for Mashrek countries, and it is perversely negative.

In case of the RLS method the 4 impact estimates are: 0.2600 (Table 2), 0.292 (Table 3), 0.271 (Table 4), and 0.644 (Table 5). At the 5\% two-tailed marginal significance level, the third estimate for the Maghreb countries, is statistically insignificantly different from zero. This is the same result as with ARDL. Also similarly to ARDL the strongest impact is for Mashrek countries with an estimate of 0.644. The estimated impacts for the whole sample and for GCC countries are quite close to each other at 0.260 and 0.292 . There is one notable discrepancy between ARDL and RLS regressions and this is the fact that the impacts are generally smaller for ARDL relative to RLS. For example the ARDL estimate of the impact for Mashrek countries is around 2.632 while it is 0.644 with RLS. It seems that the RLS estimates are generally one fourth the estimates with ARDL.

\subsubsection{Coefficient on YCAP}

The ARDL procedures, which produce four impact estimates of YCAP, estimate these impacts with high precision because the four t-statistics on these four impacts are highly significant and positive, with a lowest t-statistic of 2.840. These 4 estimates are: 0.0007 (Table 2), 0.0008 (Table 3), 0.0041 (Table 4), and 0.001 (Table $5)$.

The RLS regressions produce 3 estimates of the impact of YCAP that are statistically highly significant with the lowest z-values at 3.242. But one impact is negative, the one corresponding to the Mashrek countries. Surprisingly this impact is also statistically highly significant with a z-value of -9.997 . The estimates of the impact for the remaining three regressions are 0.0002 (Table 2), 0.0002 (Table 3), and 0.0040 (Table 5).

In the short run regressions, appended to ARDL, the variable YCAP is always statistically insignificantly different from zero. One exception however is the first lag of YCAP in the ARDL short run model for the Mashrek countries. This impact is not only significant but negative also. This is in conformity to the result obtained with the RLS model and was labelled tentatively as an anomaly. There must be a valid theoretical reason for this anomaly and one cannot treat it as due simply to sampling error, or multicollinearity.

\subsubsection{Coefficient on FX}

Seven out of eight estimates of the impact of FX on SAV are negative, and one is positive. The latter is insignificant statistically and belongs to the RLS model for Maghreb countries. The impact for the Maghreb countries from the ARDL estimation is negative, as already mentioned, but also has an insignificant t-statistic. The two estimates of the impact according to ARDL and RLS for the Mashrek countries are negative, as already mentioned, and they are highly significant statistically. In the RLS regression, the t-statistic is -5.037 , and in the ARDL regression the t-statistic is -10.819 . Moreover, the impacts are also immaterially different standing as -0.161 for the ARDL model and -0.157 for the RLS model. For the GCC countries one impact is statistically significant and another one insignificant. The latter belongs to the RLS model. The former estimate is -0.422 and is quite large in absolute value, compared to the two impacts for the Mashrek countries. The two combined impacts of FX when we run the regressions with the whole sample are unstable in significance. One is statistically significant with the RLS model and the other one is not with the ARDL model.

In the four short run regressions, only one impact is statistically significant and negative and it is that for the whole sample. The estimate of -0.203 is higher in absolute value than its long run counterparts with Mashrek countries, but less than its counterpart for the GCC countries. It seems therefore that the effect of FX on SAV for the whole sample is not long run but remains in the short run.

\subsubsection{Coefficient on BOY}

For the whole sample, GCC sample and the Mashrek sample, all six estimates of the impact of the budget balance over GDP, including the two econometric procedures, are negative and statistically significantly different from zero - in other words, higher BOY leads to a reduction in SAV. However, the two impacts for the Mashrek countries, according to ARDL and RLS, are relatively higher in absolute values, than the other remaining four, and stand at -1.104 (ARDL), and -0.789 (RLS). For the GCC countries, the estimates of the impact are -0.690 (ARDL) and -0.492 (RLS). The two impacts for the total sample of countries is a weighted-average of the coefficients for the other three restricted samples, standing at -0.490 (ARDL) and -0.320 (RLS).

There is no short run impact of BOY on SAV for the Mashrek countries. However, the remaining three estimates have all statistical significance, ranging between -0.478 (GCC), -0.947 (Maghreb) and -0.629 (total sample). Hence the negative relationship of BOY on the saving rate (SAV) is generally strongly supported and well 
established either in the long term, or in the short term, or in both. Moreover the coefficient estimates are quite close to each other. The minimum impact is -0.947 and the maximum impact is -0.478 : one dollar of budget deficit has the effect of increasing private saving inside a range between 0.5 dollars and one dollar. This is of course, as we will elaborate later, a very interesting result because it differs from a lot of international evidence (Note 23).

Table 2. Whole regression

\begin{tabular}{|c|c|c|c|c|}
\hline \multicolumn{5}{|l|}{ Method: ARDL } \\
\hline \multicolumn{5}{|l|}{ Dependent Variable: D(SAV) } \\
\hline \multicolumn{5}{|l|}{ Sample: 19952015} \\
\hline \multicolumn{5}{|l|}{ Included observations: 210} \\
\hline \multicolumn{5}{|c|}{ Model selection method: Schwarz criterion (SIC) } \\
\hline \multicolumn{5}{|c|}{ Selected Model: ARDL $(1,1,1,1,1,1)$} \\
\hline Variable & Coefficient & Std. Error & t-Statistic & Prob. \\
\hline \multicolumn{5}{|c|}{ Long Run Equation } \\
\hline GDP & 1.197795 & 0.393091 & 3.047119 & 0.0027 \\
\hline YCAP & 0.000706 & 0.000249 & 2.839948 & 0.0052 \\
\hline FX & -0.064360 & 0.054183 & -1.187824 & 0.2368 \\
\hline BOY & -0.489645 & 0.181039 & -2.704636 & 0.0077 \\
\hline INT-INF & 1.906531 & 0.414638 & 4.598066 & 0.0000 \\
\hline \multicolumn{5}{|c|}{ Short Run Equation } \\
\hline COINTEQ01 & -0.233410 & 0.064828 & -3.600475 & 0.0004 \\
\hline $\mathrm{D}(\mathrm{GDP})$ & -0.063059 & 0.101799 & -0.619451 & 0.5366 \\
\hline $\mathrm{D}(\mathrm{YCAP})$ & 0.001204 & 0.000694 & 1.735346 & 0.0848 \\
\hline $\mathrm{D}(\mathrm{FX})$ & -0.203153 & 0.082244 & -2.470119 & 0.0147 \\
\hline $\mathrm{D}(\mathrm{BOY})$ & -0.629026 & 0.097829 & -6.429837 & 0.0000 \\
\hline D(INT-INF) & -0.109133 & 0.085488 & -1.276588 & 0.2038 \\
\hline$\underline{\mathrm{C}}$ & 3.856859 & 0.887558 & 4.345472 & 0.0000 \\
\hline Mean dependent variable & 0.016814 & \multicolumn{2}{|c|}{ S.D. dependent variable } & 6.279105 \\
\hline S.E. of regression & 3.885169 & \multicolumn{2}{|c|}{ Akaike information criterion } & 5.124133 \\
\hline Sum squared residuals & 2188.708 & \multicolumn{2}{|c|}{ Schwarz criterion } & 6.281051 \\
\hline Log likelihood & -488.6546 & \multicolumn{2}{|c|}{ Hannan-Quinn criterion } & 5.591327 \\
\hline \multicolumn{5}{|c|}{ Method: Robust Least Squares } \\
\hline \multicolumn{5}{|l|}{ Dependent Variable: SAV } \\
\hline \multicolumn{5}{|l|}{ Sample: 19942015} \\
\hline \multicolumn{5}{|l|}{ Included observations: 220} \\
\hline \multicolumn{5}{|l|}{ Method: MM-estimation } \\
\hline \multicolumn{5}{|c|}{ Huber Type III Standard Errors \& Covariance } \\
\hline Variable & Coefficient & Std. Error & z-Statistic & Prob. \\
\hline $\mathrm{C}$ & 37.11123 & 4.204487 & 8.826576 & 0.0000 \\
\hline GDP & 0.259970 & 0.118700 & 2.190144 & 0.0285 \\
\hline YCAP & 0.000211 & $3.24 \mathrm{E}-05$ & 6.503895 & 0.0000 \\
\hline $\mathrm{FX}$ & -0.116213 & 0.035122 & -3.308850 & 0.0009 \\
\hline BOY & -0.319678 & 0.058954 & -5.422537 & 0.0000 \\
\hline INT-INF & -0.390894 & 0.137423 & -2.844457 & 0.0044 \\
\hline \multicolumn{5}{|c|}{ Robust Statistics } \\
\hline R-squared & 0.216403 & \multicolumn{2}{|c|}{ Adjusted R-squared } & 0.198095 \\
\hline Rw-squared & 0.338868 & \multicolumn{2}{|c|}{ Adjust Rw-squared } & 0.338868 \\
\hline Akaike info criterion & 246.7186 & \multicolumn{2}{|c|}{ Schwarz criterion } & 268.5693 \\
\hline Deviance & 13227.56 & \multicolumn{2}{|l|}{ Scale } & 7.483296 \\
\hline Rn-squared statistic & 105.6335 & Prob (Rn-sq & tat.) & 0.000000 \\
\hline & Non-rob & Statistics & & \\
\hline Mean dependent variable & 28.58469 & S.D. deper & ariable & 9.999624 \\
\hline S.E. of regression & 8.719186 & Sum squa & iduals & 16269.18 \\
\hline
\end{tabular}


Table 3. GCC regression

\begin{tabular}{|c|c|c|c|c|}
\hline \multicolumn{5}{|l|}{ Method: ARDL } \\
\hline \multicolumn{5}{|l|}{ Dependent Variable: D(SAV) } \\
\hline \multicolumn{5}{|l|}{ Sample: 19952015} \\
\hline \multicolumn{5}{|l|}{ Included observations: 84} \\
\hline \multicolumn{5}{|c|}{ Model selection method: Schwarz criterion (SIC) } \\
\hline \multicolumn{5}{|c|}{ Selected Model: ARDL $(1,1,1,1,1,1)$} \\
\hline Variable & Coefficient & Std. Error & t-Statistic & Prob. \\
\hline \multicolumn{5}{|c|}{ Long Run Equation } \\
\hline GDP & 0.084357 & 0.221175 & 0.381403 & 0.7044 \\
\hline YCAP & 0.000788 & 0.000143 & 5.510903 & 0.0000 \\
\hline FX & -0.421701 & 0.128248 & -3.288159 & 0.0018 \\
\hline BOY & -0.690562 & 0.092464 & -7.468468 & 0.0000 \\
\hline INT-INF & 0.901388 & 0.453221 & 1.988848 & 0.0517 \\
\hline \multicolumn{5}{|c|}{ Short Run Equation } \\
\hline COINTEQ01 & -0.468317 & 0.221531 & -2.114003 & 0.0391 \\
\hline $\mathrm{D}(\mathrm{GDP})$ & 0.072254 & 0.108369 & 0.666747 & 0.5077 \\
\hline $\mathrm{D}(\mathrm{YCAP})$ & 0.000323 & 0.000284 & 1.136549 & 0.2607 \\
\hline $\mathrm{D}(\mathrm{FX})$ & 0.045295 & 0.190124 & 0.238241 & 0.8126 \\
\hline $\mathrm{D}(\mathrm{BOY})$ & -0.477513 & 0.199388 & -2.394890 & 0.0201 \\
\hline D(INT-INF) & -0.123187 & 0.136503 & -0.902449 & 0.3708 \\
\hline $\mathrm{C}$ & 26.07702 & 12.49923 & 2.086290 & 0.0416 \\
\hline Mean dependent variable & 0.439738 & S.D. depend & dent variable & 8.241817 \\
\hline S.E. of regression & 4.630252 & Akaike infor & rmation criterion & 5.631218 \\
\hline Sum squared residuals & 1179.158 & Schwarz crit & iterion & 6.560220 \\
\hline$\underline{\text { Log likelihood }}$ & -214.7736 & Hannan-Qui & inn criterion. & 6.005490 \\
\hline \multicolumn{5}{|c|}{ Method: Robust Least Squares } \\
\hline \multicolumn{5}{|l|}{ Dependent Variable: SAV } \\
\hline \multicolumn{5}{|l|}{ Sample: 19942015} \\
\hline \multicolumn{5}{|l|}{ Included observations: 88} \\
\hline \multicolumn{5}{|l|}{ Method: MM-estimation } \\
\hline \multicolumn{5}{|c|}{ Huber Type I Standard Errors \& Covariance } \\
\hline Variable & Coefficient & Std. Error & z-Statistic & Prob. \\
\hline $\mathrm{C}$ & 28.21871 & 7.088793 & 3.980750 & 0.0001 \\
\hline GDP & 0.292519 & 0.149375 & 1.958280 & 0.0502 \\
\hline YCAP & 0.000213 & $4.52 \mathrm{E}-05$ & 4.701718 & 0.0000 \\
\hline FX & -0.007875 & 0.064799 & -0.121529 & 0.9033 \\
\hline BOY & -0.491796 & 0.068910 & -7.136820 & 0.0000 \\
\hline INT-INF & -0.702986 & 0.246461 & -2.852324 & 0.0043 \\
\hline \multicolumn{5}{|c|}{ Robust Statistics } \\
\hline R-squared & 0.492810 & \multicolumn{2}{|c|}{ Adjusted R-squared } & 0.461884 \\
\hline Rw-squared & 0.606679 & \multicolumn{2}{|c|}{ Adjust Rw-squared } & 0.606679 \\
\hline Akaike information criterion & 89.38182 & \multicolumn{2}{|c|}{ Schwarz criterion } & 106.6550 \\
\hline Deviance & 3935.884 & \multicolumn{2}{|l|}{ Scale } & 7.02334 \\
\hline Rn-squared statistic & 92.59205 & \multicolumn{2}{|c|}{ Prob. (Rn-squared statistic) } & 0.00000 \\
\hline \multicolumn{5}{|c|}{ Non-robust Statistics } \\
\hline Mean dependent variable & 30.46455 & $5 \quad$ S.D. depe & endent variable & 10.6955 \\
\hline S.E. of regression & 7.462292 & 2 Sum squa & tared residuals & 4566.23 \\
\hline
\end{tabular}


Table 4. Maghreb regression

\begin{tabular}{|c|c|c|c|c|}
\hline \multicolumn{5}{|l|}{ Method: ARDL } \\
\hline \multicolumn{5}{|c|}{ Dependent Variable: D(SAV) } \\
\hline \multicolumn{5}{|l|}{ Sample: 19962015} \\
\hline \multicolumn{5}{|l|}{ Included observations: 60} \\
\hline \multicolumn{5}{|c|}{ Model selection method: Schwarz criterion (SIC) } \\
\hline \multicolumn{5}{|c|}{ Selected Model: ARDL $(2,2,2,2,2,2)$} \\
\hline Variable & Coefficien & at Std. Error & t-Statistic & Prob. \\
\hline \multicolumn{5}{|c|}{ Long Run Equation } \\
\hline GDP & -0.083901 & 0.547039 & -0.153372 & 0.8795 \\
\hline YCAP & 0.004051 & 0.000741 & 5.463999 & 0.0000 \\
\hline FX & -0.129490 & 0.231895 & -0.558399 & 0.5822 \\
\hline BOY & -0.048605 & 0.109287 & -0.444745 & 0.6608 \\
\hline INT-INF & 0.693486 & 0.295593 & 2.346081 & 0.0284 \\
\hline \multicolumn{5}{|c|}{ Short Run Equation } \\
\hline COINTEQ01 & -0.035755 & 0.243273 & -0.146974 & 0.8845 \\
\hline $\mathrm{D}(\mathrm{SAV}(-1))$ & 0.111651 & 0.191342 & 0.583514 & 0.5655 \\
\hline $\mathrm{D}(\mathrm{GDP})$ & 0.232780 & 0.436893 & 0.532807 & 0.5995 \\
\hline $\mathrm{D}(\mathrm{GDP}(-1))$ & -0.099476 & 0.411019 & -0.242023 & 0.8110 \\
\hline $\mathrm{D}(\mathrm{YCAP})$ & 0.000850 & 0.000711 & 1.195076 & 0.2448 \\
\hline D(YCAP(-1)) & -0.002552 & 0.004843 & -0.526932 & 0.6035 \\
\hline $\mathrm{D}(\mathrm{FX})$ & -0.156231 & 0.210667 & -0.741602 & 0.4662 \\
\hline $\mathrm{D}(\mathrm{FX}(-1))$ & -0.057746 & 0.221016 & -0.261277 & 0.7963 \\
\hline $\mathrm{D}(\mathrm{BOY})$ & -0.946758 & 0.194891 & -4.857879 & 0.0001 \\
\hline $\mathrm{D}(\mathrm{BOY}(-1))$ & 0.313082 & 0.416020 & 0.752565 & 0.4597 \\
\hline $\mathrm{D}(-\mathrm{INF}+\mathrm{INT})$ & 0.011472 & 0.126286 & 0.090838 & 0.9284 \\
\hline \multicolumn{5}{|l|}{ D(INT(-1) } \\
\hline$-\operatorname{INF}(-1))$ & -0.010070 & 0.024133 & -0.417271 & 0.6805 \\
\hline $\mathrm{C}$ & 3.404641 & 8.818418 & 0.386083 & 0.7031 \\
\hline Mean dependent variable & 0.508083 & \multicolumn{2}{|c|}{ S.D. dependent variable } & 2.752876 \\
\hline S.E. of regression & 1.267758 & \multicolumn{2}{|c|}{ Akaike information criterion } & 2.953658 \\
\hline Sum squared residuals & 35.35861 & \multicolumn{2}{|c|}{ Schwarz criterion } & 4.413428 \\
\hline Log likelihood & -53.47072 & \multicolumn{2}{|c|}{ Hannan-Quinn criterion } & 3.530482 \\
\hline
\end{tabular}

Method: Robust Least Squares

Dependent Variable: SAV

Sample: 19942015

Included observations: 66

Method: MM-estimation

Huber Type I Standard Errors \& Covariance

\begin{tabular}{|c|c|c|c|c|}
\hline Variable & Coefficient & Std. Error & z-Statistic & Prob. \\
\hline $\mathrm{C}$ & 13.49837 & 14.80241 & 0.911903 & 0.3618 \\
\hline GDP & 0.270826 & 0.450504 & 0.601163 & 0.5477 \\
\hline YCAP & 0.003968 & 0.001224 & 3.242238 & 0.0012 \\
\hline FX & 0.045246 & 0.116870 & 0.387148 & 0.6986 \\
\hline BOY & 0.579114 & 0.241714 & 2.395866 & 0.0166 \\
\hline INT-INF & -0.000977 & 0.322764 & -0.003027 & 0.9976 \\
\hline \multicolumn{5}{|c|}{ Robust Statistics } \\
\hline R-squared & 0.168608 & \multicolumn{2}{|c|}{ Adjusted R-squared } & 0.099325 \\
\hline Rw-squared & 0.348566 & \multicolumn{2}{|c|}{ Adjust Rw-squared } & 0.348566 \\
\hline Akaike information criterion & 102.2349 & \multicolumn{2}{|c|}{ Schwarz criterion } & 113.0112 \\
\hline Deviance & 3448.486 & \multicolumn{2}{|l|}{ Scale } & 6.264492 \\
\hline$\underline{\text { Rn-squared statistic }}$ & 18.46391 & \multicolumn{2}{|c|}{ Prob. (Rn-squared statistic) } & 0.002418 \\
\hline \multicolumn{5}{|c|}{ Non-robust Statistics } \\
\hline Mean dependent variable & 30.33491 & \multirow{2}{*}{\multicolumn{2}{|c|}{$\begin{array}{l}\text { S.D. dependent variable } \\
\text { Sum squared residuals }\end{array}$}} & 9.537351 \\
\hline S.E. of regression & 8.560773 & & & 4397.210 \\
\hline
\end{tabular}


Table 5. Mashrek regression

\begin{tabular}{|c|c|c|c|c|}
\hline \multicolumn{5}{|l|}{ Method: ARDL } \\
\hline \multicolumn{5}{|l|}{ Dependent Variable: D(SAV) } \\
\hline \multicolumn{5}{|l|}{ Sample: 19962015} \\
\hline \multicolumn{5}{|l|}{ Included observations: 60} \\
\hline \multicolumn{5}{|c|}{ Model selection method: Schwarz criterion (SIC) } \\
\hline \multicolumn{5}{|c|}{ Selected Model: ARDL(1, 2, 2, 2, 2, 2) } \\
\hline Variable & Coefficient & Std. Error & t-Statistic & Prob. \\
\hline \multicolumn{5}{|c|}{ Long Run Equation } \\
\hline GDP & 2.631865 & 0.174231 & 15.10564 & 0.0000 \\
\hline YCAP & 0.000948 & 0.000249 & 3.805443 & 0.0008 \\
\hline FX & -0.160843 & 0.014867 & -10.81865 & 0.0000 \\
\hline BOY & -1.104479 & 0.038859 & -28.42270 & 0.0000 \\
\hline INT-INF & 0.000479 & 0.000267 & 1.794264 & 0.0849 \\
\hline \multicolumn{5}{|c|}{ Short Run Equation } \\
\hline COINTEQ01 & -1.011817 & 0.480351 & -2.106413 & 0.0454 \\
\hline $\mathrm{D}(\mathrm{GDP})$ & -2.184329 & 0.915694 & -2.385436 & 0.0250 \\
\hline $\mathrm{D}(\mathrm{GDP}(-1))$ & -0.423201 & 0.372635 & -1.135700 & 0.2669 \\
\hline $\mathrm{D}(\mathrm{YCAP})$ & 0.001245 & 0.002446 & 0.508858 & 0.6153 \\
\hline $\mathrm{D}(\mathrm{YCAP}(-1))$ & -0.013534 & 0.005751 & -2.353128 & 0.0268 \\
\hline $\mathrm{D}(\mathrm{FX})$ & -0.076369 & 0.041090 & -1.858561 & 0.0749 \\
\hline $\mathrm{D}(\mathrm{FX}(-1))$ & 0.201063 & 0.137526 & 1.461993 & 0.1562 \\
\hline $\mathrm{D}(\mathrm{BOY})$ & -0.029300 & 0.297446 & -0.098505 & 0.9223 \\
\hline $\mathrm{D}(\mathrm{BOY}(-1))$ & 0.340535 & 0.357427 & 0.952739 & 0.3498 \\
\hline D(-INF+INT) & 0.049992 & 0.088342 & 0.565889 & 0.5765 \\
\hline \multicolumn{5}{|l|}{ D(INT(-1) } \\
\hline$-\operatorname{INF}(-1))$ & -0.113138 & 0.126144 & -0.896897 & 0.3783 \\
\hline $\mathrm{C}$ & 18.49282 & 11.68202 & 1.583015 & 0.1260 \\
\hline Mean dependent variable & -0.696067 & S.D. depende & ent variable & 5.442900 \\
\hline S.E. of regression & 3.482260 & Akaike informa & ation criterion & 4.519200 \\
\hline Sum squared residuals & 303.1534 & Schwarz c & criterion & 5.879440 \\
\hline$\underline{\text { Log likelihood }}$ & -108.1336 & Hannan-Quir & an criterion & 5.056696 \\
\hline \multicolumn{5}{|c|}{ Method: Robust Least Squares } \\
\hline \multicolumn{5}{|l|}{ Dependent Variable: SAV } \\
\hline \multicolumn{5}{|l|}{ Sample: 19942015} \\
\hline \multicolumn{5}{|l|}{ Included observations: 66} \\
\hline \multicolumn{5}{|l|}{ Method: MM-estimation } \\
\hline \multicolumn{5}{|c|}{ Huber Type I Standard Errors \& Covariance } \\
\hline Variable & Coefficient & Std. Error & z-Statistic & Prob. \\
\hline $\mathrm{C}$ & 41.68773 & 4.171946 & 9.992395 & 0.0000 \\
\hline GDP & 0.644554 & 0.231882 & 2.779669 & 0.0054 \\
\hline YCAP & -0.002313 & 0.000231 & -9.997076 & 0.0000 \\
\hline FX & -0.156896 & 0.031149 & -5.037023 & 0.0000 \\
\hline BOY & -0.788945 & 0.095104 & -8.295620 & 0.0000 \\
\hline INT-INF & 0.000253 & 0.000616 & 0.411163 & 0.6810 \\
\hline \multicolumn{5}{|c|}{ Robust Statistics } \\
\hline R-squared & 0.531760 & Adjuste & d R-squared & 0.492740 \\
\hline Rw-squared & 0.798023 & Adjust & Rw-squared & 0.798023 \\
\hline Akaike info criterion & 74.61950 & Schwa & rz criterion & 90.13983 \\
\hline Deviance & 982.8906 & & Scale & 3.888567 \\
\hline Rn-squared statistic & 184.3755 & Prob $(\mathrm{Rn}-$ & -squared stat.) & 0.000000 \\
\hline \multicolumn{5}{|c|}{ Non-robust Statistics } \\
\hline Mean dependent variable & 24.32798 & S.D. depe & ndent variable & 8.156578 \\
\hline S.E. of regression & 4.548362 & Sum sque & ared residuals & 1241.256 \\
\hline
\end{tabular}




\subsubsection{Coefficient on the Real Interest Rate INT-INF}

Theoretically the effect of the real interest rate on the saving rate is ambiguous. If the income effect dominates then the relation is negative, whereas if the substitution effect dominates then the relation is positive. On balance then the relation could be non-existent and self-cancelling. The econometric procedures are unable to differentiate this effect. The ARDL approach produces positive impacts, with 3 out of 4 estimates being statistically significant. The fourth insignificant impact belongs to Mashrek countries. The RLS approach produces two impacts that are negative and statistically significant for the whole sample and for the GCC countries, and the remaining two are statistically insignificant. It seems that for this approach the effect of the GCC countries dominates those of Maghreb and Mashrek countries, and drives up the significance of the whole sample with all countries. There is also high variation in estimates, the minimum is - 0.703 (RLS-GCC) and the maximum is +1.907 (ARDL-total sample). In what regards short run impacts all four of them are statistically insignificant. Therefore it seems that the theoretical ambiguity is contagious to an empirical ambiguity. The ambiguity shows up in the sign, in the statistical significance of the impacts, and in the time frame.

\section{Evaluation and Policy Implications}

\subsection{Effect of GDP}

In accordance with the life cycle hypothesis, GDP growth is positively related to private savings for all the Arab sub regions. As a result, policies that favor GDP growth should be actively pursued. And the ingredients for good and sustained growth are well-known in the literature: more capital, through higher fixed investments; better capital, through quality labor and technology; and superior institutions, through decent and clean governance and the rule of law. The first two broaden and deepen capital, while the third improves its operating environment. In addition, and as frequently emphasized, there has to be concerted efforts at diversifying the economies, most notably in the GCC.

\subsection{Effect of YCAP}

The effect of per capita income on private savings has been surprisingly mixed, positive as expected for the GCC and Maghreb countries but negative for the Mashrek countries. The latter countries of Egypt, Jordan, and Lebanon are low-to middle-income countries, so the effect (i.e. lower private savings as YCAP increase) could be cultural - "catching up with the Jonses" - in the case of Jordan and Lebanon, and it could be economic in the case of Egypt in the sense of meeting still unfulfilled basic needs.

\subsection{Effect of $F X$}

The real effective exchange rate has usually a neutral effect on private savings, but for the Arab countries the effect is un-ambiguously negative, especially for the Mashrek countries. It could be that depreciations are associated with more uncertainty (Egypt comes to mind) and induce higher private savings; or, better still, the result is an outcome of more competitiveness and higher exports, particularly in the more diversified Mashrek and Maghreb countries. Hence, there is a need for a policy of moderate real exchange rates that could be rendered by pursuing lower and less variable inflation rates on part of the monetary authorities.

\subsection{Effect of BOY}

The effect of budget balance on private savings in the Arab countries - especially the Maghreb countries -- is somewhat surprising but interesting. It reveals that government savings crowd out private savings and vice versa. More specifically, this means that government deficits induce more private savings thus preventing a worsening of the CA, for given investment (Note 24). One reason behind this result could be that budget deficits signal more uncertainty. At any rate, this stabilizing role for private savings is reassuring because increasing budget deficits do not have to bleed the CA and put pressure on foreign exchange reserves and/or exchange rates - thus reducing the incidences of "triple" or even "twin" deficits. However, this also means that governments should not become profligate and throw the onus of adjustment on the private sector, since budget deficits not only increase uncertainty but ultimately crowd out investments and hurt growth in the process. This is mostly true for the Mashrek countries - Egypt and Lebanon in particular.

\subsection{Effect of Real Interest Rates INT-INF}

As expected, the effect of real interest rates on private savings in the Arab countries is ambiguous (Note 25). This could be due to the indeterminate balance between the substitution and income effects, or it could be due to religious reasons (Note 26). What this result calls for is a policy that pursues moderate real interest rates (primarily, through controlling inflation rates, and borrowing rates if possible), and that seeks a sound development of banking and financial systems. 


\subsection{Short Run vs Long Run}

A notable conclusion from the estimation results is that, except for FX, all variables have not exerted any significant short-term impact and the latter was confined to the long term. Of course, this is in agreement with the life cycle hypothesis of savings that posits the absence of any rigorous relationship between SAV and its basic determinants in the short run. More important, it indicates an interesting behavior on the part of Arab economies when it comes to savings behavior, namely, that Arab economic people have come to discount the short term. Given the frequent economic and political upheavals that plague these countries, Arabs have learned to live with their short term gyrations, and look forward to more stable long run trends. Fortunately, this implies that the seeds for long term structural reforms can be planted to reap returns in due time.

\subsection{Other Effects}

There are obviously other variables that have noticeable effects on SAV but not incorporated into equation (7). Given the current high percentage of population below 15-years of age (more than 30\%) in Arab countries, we conjuncture that in the future this is going to create a bulge in working-age population and enhance private savings. Also, private savings can benefit from striving towards less religiosity in the Arab world, not to mention the overall benefits that will accrue from reducing its extreme kind. The same goes for efforts aiming at better institutions and governance; and at strengthening FDI inflows in their design of more liberal capital and financial account policies.

\subsection{ADRL vs RLS Estimates}

With a couple of exceptions, the estimates from ARDL are usually higher than those from RLS, although one would expect the opposite, if one considers that RLS estimates are more long term than ARDL estimates. It seems that the reverse holds here: ARDL estimates are more long term than those of RLS. Theoretically the higher estimates should be for the longer term, because adjustment to shocks takes more time to dissipate completely. There is no reason to believe that one econometric method is better than the other. The differences in sign and in significance between ARDL and RLS are disturbing but can be justified by the fact that some variables are inadvertently omitted from the regressions. The reduced form theoretical equation may need to be more elaborate in order to enhance the plausibility of the model and improve the stability of the estimated coefficients.

\section{Conclusion}

Aided with the fact that private savings is a macroeconomic phenomenon, the paper developed a simple model of private savings within a macroeconomic framework for ten Arab countries comprising three sub regions from 1994 to 2015. It used novel and rigorous econometric techniques to estimate the basic determinants of Arab private savings. As a result, it found that GDP growth is very supportive of private savings, so is to a lesser extent GDP per capita. Low real exchange rates that are not overvalued are also helpful, and surprisingly so is reasonable budget deficits. The latter signifies that Arab private savings play a stabilizing influence (perhaps because of Ricardian Equivalence) in the presence of budget deficits and in the process ameliorate any negative impact on external balances. It also signifies that austerity programs designed to reduce budget deficits should go slow and should be wisely selective. Unsurprisingly, real interest rates do not affect Arab private savings, so moderate real rates through better control of inflation seems desirable.

The paper arrived also at additional interesting results. Arab economic behavior seems more geared towards the long run, an outcome that favors deliberate, structural, and long run policies and reforms. This is also an argument that makes the life cycle hypothesis as the best model to understand Arab savings behavior. Also, the Maghreb countries of Tunisia and Morocco look like they have relatively the "best behaved" economic outcomes, despite (or may be because!) their lack of oil wealth as in the GCC countries.

Perhaps the essential conclusion that we need to carry from the paper relates to the relation between private savings and growth. Arab saving rates are lower than those of emerging economies, and just as disturbing, Arab countries receive very little capital inflows to augment their domestic resources. Hence, there is a need to elevate Arab private savings through growth and the policies that facilitate it. That is also to say that private savings in turn need to be efficiently channeled to productive investments so as to create a virtuous cycle of growth and savings. Simply increasing Arab private savings is not enough -- it has to be put into productive use with large and widespread returns.

\section{References}

Akram, A., \& Akram, M. (2015). Savings Behavior in Muslim and Non-Muslim Countries in Context to the Interest Rate. Pakistan Journal of Applied Economics, 25(2), 161-177. 
Bolbol, A. et al. (2017). Savings in the Lebanese Economy: A Simple Tale for the Post-War 1992-2015 Period. Association of Banks in Lebanon Monthly Bulletin, 2.

De Castro Campos, M. et al. (2013). Private Savings Imbalances and Culture. Working Paper, Utrecht School of Economics, Utrecht, Netherlands.

Feldstein, M., \& Horioka, C. (1980). Domestic Saving and International capital Flows. Economic Journal, 90, 314-329. https://doi.org/10.2307/2231790

Hussien, K. et al. (2017). Savings, Financial Development, and Economic Growth: Egypt Revisited. World Bank Research working Paper 8020.

IMF. (2013). Balance of Payments and International Investment Position Manual, 6th edition. IMF, Washington DC, USA.

IMF. (2014). Towards New Horizons. IMF, Washington, DC, USA.

Loayza, et al. (2000). Saving in Developing Countries: An Overview. World Bank Economic Review, 14, 393-414. https://doi.org/10.1093/wber/14.3.393

Montiel, P., \& Serven, L. (2009). Real Exchange Rates, saving, and Growth: Is There a Link? Working Paper No. 46, Commission on Growth and Development.

Ozcan, M. K. (2000). Determinants of Private Savings in the Arab Countries, Iran, and Turkey. Working Paper, Bilkent University, Ankara, Turkey.

Yasin, J. (2007). Demographic Structure and Private Savings: Some Evidence from Emerging Markets. Loyala eCommons, Working Paper 9-1-2007, Chicago, USA.

\section{Notes}

Note 1. Of course, there were notable variations among countries, with a troubling performance especially for Arab countries in West Asia and some in North Africa; see IMF (2014) for an examination of these challenges with proposals on how to overcome them.

Note 2. There is no literature on the Arab countries only or on its sub-regions. See Ozcan (2000) for evidence on the Middle East countries, and Akram and Akram (2015) on the Moslem and non-Moslem countries.

Note 3. For more on the derivation, see IMF (2013).

Note 4. For instance, relatively lower savings -- or higher consumption -- coupled with excessive investment (a negative S-I) translate to higher demand for goods and services, including imports, thus rendering a deficit in the trade account and consequently the current account (a negative CA).

Note 5. More accurately, the current account is identical to the change in net foreign assets, the latter being positive in the case of CA surplus and negative in the case of CA deficit.

Note 6. In turn, private savings are divided between household and corporate savings.

Note 7. In other words, IN plus $\mathrm{C}_{\mathrm{g}}$ are equal to government current expenditures.

Note 8. See Bolbol et al (2017) for an elaboration of "triple deficits" for the post-war Lebanese economy.

Note 9. For a comprehensive survey of the evidence, see Loayza et al (2000).

Note 10. And depending on whether investment is enhanced by a fall in $\mathrm{R}$ or not.

Note 11. See Montiel and Serven (2009).

Note 12. See, in the context of Egypt, Hussien et al (2017)

Note 13. One way of interpreting this effect is by the failure of the Ricardian Equivalence theory to hold, a theory which states that budget deficits will generate more private savings because both households and corporates will save more now so as to pay for the higher taxes needed to cover the deficit in the future.

Note 14. An important determinant that requires a separate treatment is pension systems. Suffice it to say that there is increasing evidence that mandatory pension systems that are fully-funded and are characterized by defined contributions can enhance private savings - something that Arab countries should seriously consider when they ponder reforming their pension systems.

Note 15. See Yasin (2007). 
Note 16. See De Castro Campos et al (2013).

Note 17. See Loayaza et al (2000) and Akram and Akram (2015). Note that the effect of capital account liberalization refutes the Feldstein-Horioka hypothesis (Feldstein and Horioka, 1980), which argues that national savings are broadly in line with national investment and hence eliminates the need for foreign savings.

Note 18. Kuwait actually follows a peg to a basket of USD and EUR but the latter's share is very small.

Note 19. Algeria's basket shares are: 60\% USD and 40\% EUR; Morocco's basket shares are: $40 \%$ USD and 60\% EUR.

Note 20. This is in accordance with the "Impossible Trinity", which states that a country can't have monetary policy independence in the presence of free capital mobility and fixed exchange rates.

Note 21. Note that descriptive statistics are additionally reported for nominal deposit rates, inflation rates, and the current account balance.

Note 22. We have also calculated the descriptive statistics for each country and they are available on request from the authors. Interestingly, they show that the Maghreb countries, particularly Morocco and Tunisia, have the least instability in their basic variables: Tunisia for SAV and GDP; and Morocco for YCAP, FX, BOY, and INT-INF. In other words, these countries seem to exhibit a relatively "well behaved" economic performance, and this is due to three reasons: first, they are better shielded from political instability than other Arab sub-regions; second, they are insulated from the upheavals of the oil market that characterize directly the GCC countries and indirectly the Mashrek countries; and third, they seem to conduct better management of their economies, as reflected for instance in their less rigid exchange rate policies.

Note 23. See Loayza et al (2000).

Note 24. This also indicates a vindication of the Ricardian Equivalence theory; a similar result is obtained by Ozcan (2000) for Middle East countries.

Note 25. This ambiguity is also obtained by Ozcan (2000). In contrast, Hussien et al (2017) find that lower real interest rates in Egypt reduce private savings because they enable more consumption (the liquidity constraint effect), a result that agrees with the view of "unmet basic needs" alluded to earlier in our paper.

Note 26. Akram and Akram (2015) find that real interest rates are positively related to private savings in non-Moslem countries, but indeterminate in Moslem countries since Islam prohibits interest.

\section{Copyrights}

Copyright for this article is retained by the author(s), with first publication rights granted to the journal.

This is an open-access article distributed under the terms and conditions of the Creative Commons Attribution license (http://creativecommons.org/licenses/by/4.0/). 